\title{
The Role of Japan in the Reconstruction of $\operatorname{Iraq}^{(*)}$
}

A.P.Dr. Samir Radhi ${ }^{(*)}$

\section{Supervised By Professor Keiko Sakai}

\section{Introduction}

In 1945, Japan had gone through a situation similar in some aspects with the one Iraq is going through. True, circumstances are completely different between that time and the present, but the basic principles and values of building have not changed. The circumstances that surrounded Japan at that time were different on the internal, regional and international levels. They all contributed positively to the rebuilding of Japan, contrary to that, are the situation surrounding Iraq at present.

Japan has vital interest in Iraq, not concerning the economic one, but the political interest too. Therefore, helping Iraq to become a stable and secure country is appositive value to Japan. Iraq and Japan have so many similar elements and interests that; they can build upon, economically, and politically. With Japanese technology and mentality and Iraqi oil, the two countries could build a great peaceful relations, which would benefit the people of their countries and the other state in the region.

Having stable and secure Iraq, would lead to the stability of the whole region, which is considered as a very vital to the interest of Japan. If Japan's efforts succeed in the reconciliation process and the reconstruction of Iraq, then, its interest would be maintained and expanded. If Iraq fails to become a positive element in the region, then Japan's interest would be at risk, especially most of its energy imports come from the Gulf States and Iran.

Iraq needs at the present time political assistance from Japan, especially in the area of reconciliation. Most of the causes of conflict in Iraq are due to the differences between the political, economic and social forces comprising the old and the new elite in Iraq. There is a problem of distrust between those elites. This 
distrust has been reflected in bloody violence for the last five years.

The major question of the paper would be, how could Japan assist Iraq in making the process of reconciliation less painful and successful and then to move on with the process of construction? I have also, raised many questions in order to be answered through out the paper. Did the two countries enjoyed good relations? Do they have strong incentives and interest to get together and achieve this goal? What did the JSDF do in Almuthana province? Did their presence contributed to the continuity of calmness through the achievement of many small scale service projects? The answer to those questions would constitute the major part of the paper.

I have divided the paper into three sections. The first, would be dealing with the historical background of the relations between the two countries. The second would be dedicated to the JSDF humanitarian functions implemented in Al muthana province. The third would be concerning the role of Japan in the process of reconciliation.

\section{The historical background}

In July 1968, a new government took over power in Iraq, and was ideologically oriented against the west. It adopted certain political values in its relations with other countries. The most important of those values was the political position those countries are taken toward Arab issues especially the Palestine issue. The seriousness of the active participation of that country in the process of the economic and social development, especially what was concerning the willingness of the transfer of technology and the training of Iraqi workers and qualify them to manage the economic activities sufficiently, was the other important political value. Japan in this category, was considered as a friendly and neutral state despite the fact it was an American ally.

Iraq had never comprised an important partner of japans foreign trade since the two countries have started their economic 
relations in the early years of the seventies of the last century. But, Japan had been one of the major partners of Iraq, especially in the construction projects and the export of heavy machinery.

The real economic relations between the two countries started after the success of the nationalization of Iraqi oil in 1974.pragmatic reasons had called for such cooperation. Chief among them, the threat Japan realized after the second oil crisis imposed after the October war in 1973 between the Arab states, namely (Egypt and Syria) and Israel. The lessening of the tune of anti-American slogans in Iraqi foreign policy was the second reason. The need by Japan to expand its economic activities internationally and especially in the gulf region to secure its import of oil was the third reason. 2

In, 1975, Iraq announced a very ambitious development plan for the coming 20 years. The plan included many heavy industrial projects. Western companies were reluctant to work in Iraq because of the unfriendly relations between their countries and Iraq over the nationalization of their shares in Iraqi oil 3. As a consequence, Japanese companies became the major ones to depend on by the Iraqis in implementing the heavy projects. Japan was considered by the Iraqi government back then, as an honest and accepted economic partner, despite the fact that, it was an American ally. The era of the 1970s, witnessed the supremacy of Japanese companies on most of Iraqi contracts until the early years of the 1980s, when western companies started to enter the Iraqi market, due to the bad effects of the war between Iraq and Iran 4.

The volume of trade between the two countries reached its highest level for the years 1978 - 1981. Through out the years 1977 - 1981, Iraq depended on Japan for $20-25 \%$ of its import, especially as a supplier of important commodities such as industrial machinery, iron, steel and automobiles. As for Japan, it imported only one commodity from Iraq, which is oil. It was the second largest after France, in 1980, third, after turkey in 1981 and 1982. 
Diplomatic and economic relations was at its most high during most of the years of the 1980s.this was symbolized by the visits of many senior officials of the two countries. Chief among those visitors was kibe yoshiaki, the chairman of the Japan - Iraq parliamentary friendship association, who visited Iraq in the 1980s. Iraqi ministers also visited Japan during that period to reaffirm the strength of those relations. However, this pattern of relations continued during the 1980s despite the continuation of the devastating war between Iraq and Iran 5.

In 1980, Iraq used to have an approximation of $32 \mathrm{~b} \$$ at the I.M.F of the so called (special withdrawing rights). By the year 1984, Iraq started to ask countries including Japan to grant it credits in order to pay for the continuation of the war efforts, and at the same time pay its required dues to the foreign companies working in Iraq. Many companies started to leave Iraq without finishing their projects. Japanese companies did not leave Iraq, because of the understanding reached between the two governments based on the 1977 loan agreement. Japans major objective of all that is to secure a good share of oil in the huge oil reserve in Iraq which was approximated to 112 BB in 1978.

After the end of the Iraq Iran war in august of 1988, Iraq announced his intentions of having a joint development projects to develop its oil reserve with foreign companies, most important of them are Japanese companies. Japan was considering seriously the active participation of such a program, but, the invasion of Kuwait by Iraq stopped all these hard working plans of securing and for along times some of the needs of Japan to Iraqi oil 6.

In a quick response to the invasion, and, in an unexpected move, Japanese government voluntarily imposed sanctions on Iraq, before the sanctions system imposed on it by the United Nations. In October 1990, Prime Minister Kaifu Toshiki met with Iraqi first deputy Prime Minister Taha Yassin Ramadan in Amman, among the things he said was, the advice to the Iraqi government not to repeat the mistakes made by the imperial 
Japan in the 1930s. Gradually, Japan hardened its position toward Iraq, to the point of employing expressions that had never used by any Japanese government describing acts taken by any Arab state in the past, such as brutal and aggressor. In December of 1990, the Japanese embassy in Baghdad was closed, and relations were frozen, especially after the taking of Japanese hostages by Iraqi government 7.

During the period between the gulf war and the 2003 U.S.A invasion of Iraq, there were no diplomatic relations between the two countries.

Nevertheless, in 1995, the United Nations established the oil for food program 8 . This program would allow Iraqi government to export certain amount of its oil in order to pay for the costs of the UN committees working inside Iraq pay for the compensation of the invasion to Kuwait and the last objective would be to help Iraqi people not to suffer and die.

As a consequence, the Japanese government started showing interest, under encouragement from business firms, in resuming the once strong economic relations with Iraq.

Japanese general trading companies started to negotiate with Iraq, and signed a deal on oil imports to Japan in December 1996. Business enthusiasm to seize opportunities in the Iraqi market led to a visit to Iraq by an L.D.P leader, the president of the Japan -Iraq Diet member's friendship league, Kyuma Fumio and MOFAs MEAB director 9.

At the end of the year 2000, those who were concerned with Iraq economic opportunities pushed the government further, to reconsider the opening of its diplomatic mission in Baghdad and to amend the cabinets economic sanctions imposed earlier on Iraq. However, these moves were halted in the face of sharp U.S.A disapproval, which resulted in japans virtual abandonment of participation in the oil for food program 10.

\section{The humanitarian mission of the SDF}

Japanese forces had served in Iraq for about two years in the province of al-muthana. They have accomplished so many 
projects serving the people of the province. The people of the province were not hostile to the forces and cooperated with them. The question which to be asked, is, did Japan choose this province to give its services to it, or it was chosen for it?

Al-muthana is a small Iraqi province. It is located in the southern part of Iraq. It is bordered by many Iraqi provinces. From the north, it is bordered by Al dewania province. To the east, it is bordered by kut province. To the west, it is bordered, by Saudi Arabia. To the south, it is bordered by Al nasyria province. It is a very poor and neglected area. Its inhabitants are mostly Arabs who belong to many Arabic tribes. Most of the people there are strongly loyal to tribal customs and traditions.

In the year 2003, and after the invasion of Iraq by the United States and its allies, Japanese government decided to send Japanese military contingent for civilian work to participate in the reconstruction of Iraq. This contingent of the Japanese self defense forces (SDF) called "the Japanese Iraq Reconstruction and Support Group, JIRSG "11. The sending of this contingent marks an important turning point in japans history. It has represented the first foreign deployment of Japanese troops since the Second World War, outside the framework of the U.N peace keeping operations 12 .

Public opinion regarding the deployment, was sharply divided, especially article 9 of the Japanese constitution prohibits the use of military forces unless for self-defense purposes. In December 2003, and in order to legalize this decision, the Japanese government passed legislation under the name the" Humanitarian Relief and Iraqi Reconstruction Special Measures Law"3. At a press conference on the same day, Prime Minister Koizumi, emphasized that" this dispatch of the SDF is for humanitarian and reconstruction assistance in Iraq. They will not engage in the use of force. They will not participate in combat activities. They are not going to war" 13 .

In January of the year 2004, the Japanese SDF arrived to Almuthana governorate where they were assigned to conduct 
civilian humanitarian projects which would better the life of the people of samawa, and to keep the forces a way from any military attacks, which was the most important motive ever for the Japanese public.

There are many views analyzing the sending of Japanese troops to Iraq. One of those views stressed the fact that, this event "represents the emergence of Japan as a close military ally of the United States, strategically positioned as a counter weight to Chinas regional power14. Another view stressed that, the whole deployment process is symbolic as it comes at little financial or human cost to the Japanese government, has a negligible effects on the strategic situation in Iraq, and simply aimed at maintaining positive relations with the U.S.A, in order to enhance a favorable economic relationship 15.

The province, in which the SDF were assigned to work, has continuously been a relatively stable area among the southern governorates. Safety of the forces was number one priority to the people and the government of Japan. For this fact, samawa was selected to be the place for the deployment and work of the SDF. The forces were assigned to work in only civilian projects such as, water purification, rehabilitations of schools and hospitals, the pavement of new roads and building new bridges, and the transportation of materials such as these for humanitarian and reconstruction use, and other assignments related to civilian projects only. The contingent was allowed to be equipped with" bulldozers, wheeled armored personnel carriers, light-armored mobile vehicles, and other types of vehicles, and weapons necessary for the safety of personnel (pistols, rifles, machine guns, recoilless rifles, and light anti-tank munition"16. in July of the year 2006, the Japanese contingent completed its withdrawal after it was delayed for six months. It finished most of the projects assigned to them.

The local inhabitants of almuthana province including the city of samawa had a positive response to the presence of the SDF. They strongly welcomed the Japanese contingent, according to a 
series of opinion polls conducted in almuthana province. More than eighty percent of the respondents in the year 2004 supported the presence of the SDF. This figure fell in the final stages of its operations in the year 2006, but still was as high as seventy three percent7.One explanations to this slight drop in the number of those who supported the SDF in that province is due to the high rate of unemployment. This factor could be attributed to the deteriorated conditions of the agricultural sector, in addition to the inexistence of significant industries. The people of samawa had high expectations that the SDF would create employment, attract many Japanese private companies and renovate the entire devastated infrastructure. But the mission of the SDF as was mentioned, was confined to small-sized reconstruction activities and did not bring any Japanese companies into the area17.

Taking into account these high expectations, the strong support that the SDF was able to generate and maintain until its withdrawal can be interpreted as an indication that, its humanitarian efforts had a positive impact on the local inhabitants.

\section{The Role of Japan in the Reconciliation Process}

On the $9^{\text {th }}$ of April 2003, the old political, social, economic structure of the Iraqi state, which was formed in 1920, collapse after the takeover of the united states of Iraq. This resulted in the creation of a new elite composed by those forces who were abroad opposing the old political regime. The majority comprising the old elite migrated to the Arab neighboring countries mostly Jordan, Egypt, and Syria. Some of the members constituted the old elite stayed in Iraq. The two elites did not trust and accept each other and exchanged accusations of committing many different atrocities. The result of those differences was an armed conflict which started at the early days of the takeover. The fight between the component of the new elite and the rampant of the old elite, took many different names. The two conflicting groups were supported by all the neighboring countries. 
Many conferences were held in the neighboring countries to ease the support giving to those fighting factions in Iraq and to reduce the fears those countries realized after the occupation of Iraq by the United States, and its claims of supporting the spread of democratic principles throughout the Middle East. But, unfortunately, none of those conferences succeeded in reducing the fight in Iraq. Iraqi civilians have lost tens of thousands of victims as a result of those fighting. In order to reduce the intensity of fighting between those conflicting factions, and the number of civilian casualties, informal contacts and talks started on an informal channels between the representatives of many of fighting factions and the government. Contrary to all expectations of getting the fight to a lower level, on February 2006, an explosion in the city of samara- which is to the north of Baghdad- to a holly shrine contributed severely to the spread of violence all over Arabic Iraq. By that time, Iraq contained many military factions of the Muslim religious sects in Iraq. All those factions engaged in a street fights, and had almost total control over their neighborhood.

The government in Baghdad by that time was too week to fight against those factions and protect its civilians. But, a new government was formed in May of the same year. This government was working hard with the Americans to get Iraqi police and army officers highly trained. They formed new brigades of police and called them national brigades who would work any where in Iraq if needed. At the same time, they started the honest process of purging the old force of police and the army from those who were not loyal to the authority in Baghdad. This factor has contributed positively to the lessening of the rate of fighting and reducing the number of civilian casualties, gradually.

By the end of the year 2006, the government started anew political process to bring conflicting factions in Iraq to participate in a conference, and exchange their views. This process is called, the process of reconciliation between all the components 
comprising Iraq, politically, socially, and on all other levels. During the intense fighting at the end of the same year, a major conference for reconciliation was opened in Baghdad, and it was attended by the prime minister and the representatives of many of those armed groups opposing the government. After that conference, the number of opposing groups started the talk with the government and gave up carrying the weapon against it increased. The year 2007 witnessed the continuation of such a trend, and the number of civilian casualties continues to go down. Relative calm is getting back to most of the country. Iraq is an important state in the region of the Middle East. It has been considered as one of the most important political, economic, and social pillars in the region. It is a rich state, not only with its natural resources, but also, with its educated human resources. It is considered to have the third largest reserve of oil according to the figures of the year 1978 .

Iraq has been in a state of war since the year 1980. It fought many wars since then. The first was against Iran, and lasted almost eight years. The second was when Iraq invaded Kuwait in 1990. As a consequence to this act, the United States of America waged an international war against Iraq in order to expel it out of Kuwait in 1991. Also, a sever program of sanctions imposed on Iraq in august 1990, by the United Nations Security Council. This program which lasted for 13 years was worse than any devastating war waged by or against Iraq. It ruined Iraqis socialinfra structure very slowly. In the year 2003, the sanctions program succeeded in emptying Iraq of its institutional strength, the united states took the lead in an step opposing to the international legitimacy and without the permission of the united nations security council, invaded the week and exhausted Iraq. This we hope to be the third and the last war ever to be fought by Iraq. All those wars have led to the total destruction of Iraq on all economic, social, political, cultural levels.

In an effort to start rebuilding Iraq, many states have participated in conferences sponsored by specialized international 
agencies, dedicated to the reconstruction of Iraq. Japan was the second donor of the states participating at the Madrid conference in October 2003, after the United States. It donated an amount equal to 5 billion dollars. 1.5 billion dollars has already spent of it to NGOs, and small projects in Iraq*.

It has been projected by specialized economic and financial international agencies that, the cost of the reconstruction of Iraq will exceed 250 billion dollars for the coming ten years. This figure represents a major work to the industrial states and their companies. Japan is one of the most important states among those countries.

Iraq is a well-known state and market to Japanese companies. They know the ability and capability of this promising state. Japanese companies had signed hundreds of contracts with the government of the old Iraq in the last century, and mostly during the seventies and most of the eighties. The accomplishment of those projects gave the Japanese, a high reputation among Iraqi people which doubled the respect and love Iraqis have for Japan and Japanese people. It, also have granted the Japanese companies a priority among Iraqi officials on all levels.

In order for the reconstruction process to start, Iraq needs to be a very stable and safe place to work at. Major companies from all over the world including Japanese companies has refused to work in such insecure environment. Reconciliation is one of the most important prerequisite to the stability of Iraq. Such a process would lead to the creation of a strong government which would be capable of controlling Iraq and provide protection to its citizens and to all foreign companies and workers.

Reconciliation in simple words means, finding a way to live along side former enemies - not necessarily to love them, or forgive them, or forget the past in any way- but to coexist with them, to develop the degree of cooperation necessary to share the society. In other words, it means that, it is a process through which a society moves from a divided past to a shared future. 
In order for the reconstruction process to start, Iraq needs to be a very stable and safe place to work at. Major companies from all over the world including Japanese companies have refused to work in such insecure environment. Reconciliation is one of the most important prerequisites to the stability of Iraq. Such a process would lead to the creation of a strong government which would be capable of controlling Iraq and provide protection to its citizens and to all foreign companies and workers.

Reconciliation in simple words means," finding a way to live alongside former enemies- not necessarily to love them, or forgive them, or forget the past in a way- but to coexist with them to develop the degree of cooperation necessary to share the society with them"18. In other words, it means that, it is a process through which a society moves from a divided past to a shared future. Reconciliation in post conflict societies cannot be imported from outside. Foreign actors must see their role as one of support and facilitation of domestic politics.

Foreign actors which are participating in the assistance of a state achieving its reconciliation process must be aware of the specific political, cultural, and historic forces in a transitional society. They must be accepting the fact that, the process is locally owned and directed. They must be very sensitive to the timing and the move of any issue among the parties of the reconciliation process.

Foreign participants must avoid supporting one sided approach. This is because, the process of transition from violence to peace is indeed almost unavoidable unique. Reconciliation processes are not similar in all countries, because of many different reasons among them19:

1. The impact of such factors as the nature, scale, and degree of violence.

2. The old and the post transition balance of power.

3 . The intensity of division in the society.

4. The strength of the political will to tackle the question of reconciliation. 
5. The capacity and resources, both inside the political leadership and in the civil society.

Iraq has already started the process of reconciliation on the formal level.

The first formally sponsored conference by the Iraqi government for the reconciliation between Iraq political forces, was held in Baghdad on the $16^{\text {th }}$ of December 2006. It was held under the auspices of the Prime Minister Mr. al-maliky. It was attended by the majority of the political forces which are participating in the ongoing political process, and those who are out or opposing it. The forces participating in the conference had a free dialogue, discussion and arguments without any intervention or dictation from the government or any other dominant force. All political forces who participated in the works of the conference agreed on the relative success achieved, especially for a conference to be formed by the government for the purpose of reconciliation.

During the summer of the year 2006, and on the informal level which preceded that conference, many conferences were held among Iraqi tribes, NGOs, political parties, and many others, reaching the level of small communities and towns. Those conferences were successful by all means of that time. They contributed highly to the reduction of tension and violence inside their communities.

The purposes of those conferences were to ascertain the cohesiveness among Iraqi people, to strengthen the rules of national unity, and spread the atmosphere of love and harmony among the different component of the Iraqi people, in order to treat the negative effects which were imposed by terrorism and administrative corruption. For those purposes and others, the reconciliation process was announced.

The reconciliation process which has been going on since then is depending on two important principles20:

1. The principle of adapted mechanism. 
2. The principle of required policies.

\section{First:}

The adapted mechanism included the followings:

1-the formation of a supreme national commission by the formal conference and name it as "the national commission for the project of reconciliation and national dialogue". Members of this commission belongs to, the three authorities (executive, legislature, and judiciary), the state minister for national dialogue, and representatives from all the political coalitions participating in the political process at the parliament.

2- The formation of sub national committees inside all Iraqi governorates.

3- Holding conferences to the different components of Iraqi society, such as:

A- A conference for religious scholars, to support the process of reconciliation and issue a fatwa (to legitimize the reconciliation spiritually).

B- A conference for tribal chiefs from all Iraqi governorates. This conference issued a pact prohibiting the fighting and killing Iraqis, and also to condemn terrorism and corruption.

C- A conference for political parties and organizations. In this conference, they would have to make a pledge to support the state of Iraq, to protect the ongoing political process, and confronting all types of terrorism and corruption.

D- An open call to all NGOs, to start activities aiming at educating the public of the objectives of reconciliation.

\section{Second:}

The principles and the required policies included twenty four principles, chief among them are:

1. The government first, and, then, the other political parties and organizations, must adopt a rational methods to its public speech. It also, must assert on the principle of neutrality of the media in order to enhance the trust toward the government, especially for 
those who are hesitating to make any contact with the government and consider it as a biast government.

2. Adopt the honest national dialogue with all the political forces and visions, apposing the government and its allies.

3. Adopt the legal and constitutional legitimacy to solve the problems of the country, and to deal with the violent phenomenon of killing, and exert real and honest efforts to control it.

4. Work on preventing all human rights violations inside government institutions, and work harder on rehabilitating all prisons and detentions places, and punish all those who committed the crimes of torture. Facilitate visits by international and national organizations to all those places.

5. Eliminating all obstacles which are preventing any Iraqi citizen from participating in any organization, he or she would like to work at, as long as, it is working in accordance with the constitution.

6. The armed forces must not be subjected to any political influence of those forces participating in ruling the country, and at the same time, the armed forces must not interfere in the political process.

7. The activation of the role of the judiciary in punishing criminals, and consider it the only authority responsible for that.

8. The initiation of a grand construction campaign in all the regions which were struck in conflict and treat honestly the problem of unemployment.

The continuation of political violence and the sectarian tension, and the inability of reducing it, is threatening Iraq as well as the whole region. Iraqi political and security situation is considered by many, as a critical one. Therefore, every body should do his best in order to unify all efforts for the stability and safety of its people. Iraqi government must work harder on deploying its relations with all the neighboring countries for the interest of Iraq. It is not in the interest of the neighboring 
countries the continuous deterioration in the political and security situation in Iraq. Therefore, they have to contribute positively to the reduction of political violence in Iraq, through giving an active and neutral support to all Iraqi political and social forces that are supporting the ongoing process of reconciliation.

After the end of the conference on the $17^{\text {th }}$ of December 2006, many Arab and all neighboring countries have welcomed the holding of the conference and pledge their support and good intentions to help in holding similar conferences in their countries in the future.

The reconciliation process does not end, and achieve its goals in a conference or a series of conferences; it is rather, a long and painful process. It requires the help of those participating and those who are not participating in the political process in Iraq. Reconciliation process is a locally based process, but it needs the help of outside countries and international organizations. Many countries and international organizations such as the United Nations, and the Arab league have helped in gathering many Iraqi factions and start a useful dialogue. Japan is one of the countries which have a great interest in making this process succeed. It has already made good contributions to many NGOs to help in the continuation of this process*.

Reconciliation process is a lengthy and complicated one. It is highly locally based process, which involves many emotions by all conflicting forces on the short run. It is a healing process to the whole society which was struck severely by violence. For this reason, foreign volunteers aiming at assisting in achieving the goals of this process must stay away from mediating in this phase. Japan's role would be very essential and effective when it participates as a state and not just companies helping in achieving the reconciliation process goals in the middle and long run phases. The most needed assistance in those two phases would include the following proposals:

1. The active participation in the rehabilitation process of schools, hospitals, training centers. This process must be 
implemented up to the Japanese standards and not Iraqi standards of the present time.

2. Japan could assist in running an advertisement campaign focusing on the reconciliation among the components of Iraqi society, through showing all the positive effects of stability in the society. There is a campaign which is run by an institution inside Iraq and is giving to be showed as commercials to all Iraqi TV channels and many Arabic speaking channels. It has been accepted by all Iraqi people, because it is focusing only on Iraq, and nothing else. The same program could be initiated by Japanese government in order to assist in the reconciliation process. Japan would publicly announce its name as the promoter of the program for the purpose of helping Iraqi people. The major focus of the program would be Iraq as the homeland of all the components sharing the communities. The programmed campaign would also stress on some good aspects of the good life and value system in Japan. Those principles would be appealing to Iraqis, and make them think cooperatively with others who share the same neighborhood. Iraqi society accepts the cooperative communal means of working together, and it is not a society based on individualism, therefore, such a campaign would be very effective.

3. Japan could voluntarily work on rehabilitating the training centers at all Iraqi ministries and especially the training centers of the ministry of education. This ministry used to have very advanced centers equipped with up modern equipment of its time. But, due to the bad effects of the sanctions system, imposed by the UN Security Council on Iraq, those centers lost most of their importance. On the $9^{\text {th }}$ of April 2003, those centers had been burned and looted, like all states institutions in Iraq. Japan could help in building better training institutions and equipped them with the best equipment necessary for the qualifications of Iraqi teachers. Those centers would be administered by Iraqis who would be trained in Japan. But, the training teams would be from Japan. Such classifications of management level would help in 
encouraging teachers to participate more in such programs. Also, those centers would be a help in gathering the newly graduated teachers and expose them to the new techniques of teaching which are suitable to Iraqi social environment. Those centers would contribute very positively to the reconciliation process, on the middle and long run phases. They are going to gather Iraqi teachers from all parts of Iraq and train them with the same techniques which would enhance the unity of Iraq and make the reconciliation process more successful.

4. Concerning health sector, Japan could do the same on the education training centers, and they would be very successful in their contribution to the reconciliation process.

Those proposals concerning the training centers could be done through a direct contact or mutual meetings between the officials at the specialized institutions of the state of Japan and the state of Iraq. They also could be implemented through the cooperation between the state of Japan and the specialized agencies of the United Nations, such as the UNESCO or the WHO.

It is very obvious that, Japan is highly interested in securing the internal situation in Iraq, so that, Iraqis would be able to start the real political and economic development of their country, which has suffered and lost huge number of its people. One proof of evidence for that, is, Japan, is the second to the United States at the Madrid donor conference in October of the year 2003. It has donated $\$ 5$ billion, and has already spent about $\$ 1.6$ billion of it on different services and rehabilitation projects inside Iraq. It has also, hosted more than 2500 Iraqi employees for training and re -qualification purposes. They had come from different parts of Iraq. They had taken many training sessions in different field such as engineering, technicians, teaching in different levels of schools, administration, and many other fields.

The state of Japan could also help in succeeding the reconciliation process through its financial support to the United Nations specialized agencies and the different kinds of NGOs. 
This kind of work could be implemented through a direct contact between the specialized Japanese institutions and those NGOs or organizations. There are so many Japanese NGOs, interested in giving assistance to Iraqis, but lack the real financial capabilities. There are many Iraqi NGOs, which are working on getting the conflicting parties inside and outside Iraq, into conferences, meetings to exchange their views peacefully and without any preconditions to start the talk. They are working in a very dangerous situation and need to be supported and make the process succeed.

\section{Conclusion}

Japan and Iraq had enjoyed good relations based on mutual interest. Japan needed oil; Iraq needed construction companies of all types, and imported heavy equipment too. This period which was mostly overwhelmed by satisfying economic needs lasted from the year 1974 till the end of the eighties.

With the dramatic change which has taken place in Iraq after the $9^{\text {th }}$ of April 2003, Iraq is going to be sharing similar political and economic values with Japan. For that reason, Japan is going to play a more important role than it did in the seventies and eighties. Japan with the help of other countries, is very inclined to make Iraq becoming a stable and safe state, so that, it can function properly and be beneficial to all those who are interesting in cooperating with it.

Japan has already participated- even on a small scale- in the process of the reconstruction in Al muthana province, which has been relatively the safest place in the south of Iraq. There are several variables responsible for that safety, but we could say and based on the positive response giving by the majority of the inhabitants of Al muthana province, concerning the presence of the Japanese forces, it had contributed positively to the relative calm. The work of that forces- no matter how small it was- gave the people living there hope that tomorrow will be better than 
today. This kind of thinking makes people keener to be peaceful in their behavior than violent.

Finally, I believe, and based on the new political, economic, and social facts that are developing in Iraq since the year 2003, Japan is going to play a greater role in the economic and political development of the new Iraq. It would contribute significantly to the process of reconciliation which has been going on for the last two years, and for simple reason, no reconciliation means no stability. I believe that, the excitement and eagerness of Japan to help Iraq would not be a failure; on the contrary, it would be a story of success.

\section{End Notes}

${ }^{(*)}$ This paper has been written in Japan for the program of Japan fowndation.

1- Taih A. kareem, "Iraqi-Japanese relations as an example to the relations between developing and industrial countries", journal of Arab oil and gas, vol.17, no.4, April 1981. p.23

2-Salah H. Mohamed, "japans foreign policy toward Arab countries", unpublished thesis, Baghdad University, college of law and political science, 1982, Iraq. p 463 3- The world of oil bulletin, vol.12, no. 10, October, 1979. p. 10

4- salah Mohamed, op. cited p 465

5- Kekio Sakai, "oil for food as a political tool for Iraq", edited book, "from storm to thunder", institute of developing economies, Tokyo, March, 1998. p. 66 6-yukiko miyagi," japans middle east security policy", unpublished dissertation, 7-Al-qabas newspaper, no.3097, Kuwait, 26-12-1980. p. 13

8- kekio sakai, op. cited p 66

9- kekio sakai," Japan- Iraq relations: the perception gap and its influence on diplomatic policies," Arab Studies Quarterly, fall, 2001. pp 6-7

10- yukikio miyagi, op cited p 167

11- Keiko Sakai, "stories of our boys', but for whom? The Japanese media's coverage of the SDF in Iraq ", international journal of contemporary Iraqi studies, vol. 1, no. 3, 2007. p 352

12- http://en.wikipedia.org/wiki/japanese iraq _ reconstruction_and support_ group

13- Keiko Sakai. "stories of our boys" op cited 
14- ibid. p 353

15- Shirzad azad, "Japan's gulf policy and response to Iraq war", the Middle East review of international affairs, vol.12, no. 2- June 2008.

16- keiko sakai, "stories of our boys", op cited p352

17- Akiko yoshioka, "Japan's foreign policy toward Iraq after 2003: perceptions in Iraq and the Arab world", gulf, issue no. 2, July 2007. p 22

18- David Bloomfield, "Reconciliation after violent conflict", International Institute for Democracy and Electoral Assistance, Sweden, 2003. p.12 19- ibid. p.163

20- Mazen Al-Yasiry, "The first conference held for Iraqi political forces for reconciliation", Ministry of National Dialogue, Baghdad, March 2007. pp.52-86

*- Refers to Appendix 1.

\section{Appendix 1}

\section{Japan's Assistance to Iraq (Fact Sheet)}

June 2008

\section{The Government of Japan}

\section{Overview}

(1) At the International Donors f Conference on the Reconstruction of Iraq held in Madrid on 24 October 2003, Japan announced its financial assistance package totaling up to $\$ 5$ billion. The package comprises $\$ 1.5$ billion of grant aid for immediate needs reconstruction of living standard of Iraqi people including power generation, education, water and sanitation, health and employment, as well as improvement of security and up to $\$ 3.5$ billion, mainly in the form of Japanese ODA loans, in order to meet medium-term needs.

(2) $\$ 1.69$ billion of grant aid has been obligated and has already been disbursed. Reardin Javanese ODA loans, the Exchange of Notes $(\mathrm{E} / \mathrm{N})$ for 12 Japanese ODA loan projects (up to $\$ 2.45$ billion) have been signed in the fields of transportation, energy, industrial plant. irrigation and so oi.. Moreover, based on the agreement of the Paris Club, the Government of Japan and the Government of Iraq signed the agreement upon the debt relief on November 24, 2005 in Tokyo. The debts will be cancelled by $80 \%$ in total in three stages, which will amount to a reduction of approximately 710 billion yen (US $\$ 6$ billion).

(3) In February 2007, Japan decided to extend new emergency grant aid totaling 
avvroximatelv $\$ 100$ mfflion to assist the new government of Iraq, which has been making efforts innation-builthng including the formulation of the International Compact with Iraq under the difficult conditions of intensified religious and ethnic conflicts. In November 200 f?. Janan decided to extend new emergency grant aid totaling approximately $\$ 5$ million. In February 2008. Javan decided to extend. through UNDP. a grant aid for conflict prevention and peace building of about 16.35 million US dollar to the Project for Establishment of a Maternity and Children Hospital in Falluiah.

2. Grant aid and technical cooperation (approximately $\$ 1.69$ billion)

(1) Direct assistance for Iraq (approximately \$ 916 miffion including technical cooperation for 2430 personnel in total)

(2) Assistance through International Organizations (approximately $\$ 242$ million)

(3) Assistance through the International Reconstruction Fund Facility for Iraq

(\$ 490 mfflion: \$ 360 million for UNDG ITF, \$ 130 million for World Bank ITF.

(4) Assistance through International Finance Corporation (IF (\$ 10 million)

(5) Assistance through NGOs (approximately \$ 27 million)

\section{Japanese ODA loan (up to $\$ 3.5$ billion)}

The Exchange of Notes (EIN) for 12 Japanese ODA loan projects (uv to $\mathbf{\$ 2 . 4 5}$ billion) have been signed.

Port Sector Development Project (approx.\$260 million)

Irrigation Sector Loan Program (approx.\$80 million)

Al-Mussaib Thermal Power Plant Rehabilitation Project (approx.\$310 million)

Samawah Bridges and Roads Construction Project (approx.\$30 million)

Engineering Services for Basrah Refinery Upgrading Project (approx.\$20 million)

Khor AFZubair Fertilizer Plant Rehabilitation Project (approx. $\$ 160$ million)

Crude Oil Export Facility Rehabilitation Project (approx.\$450 million)

Electricity Sector Reconstruction Project (approx.\$290 miffion)

Basrah Water Supply Improvement Project (approx. \$370 million)

Electricity Sector Reconstruction Project in Kurdistan Region (approx. \$130 million)

Water Supply Improvement Project in Kurdistan Region (approx. \$342 million) Baghdad Sewage Facilities Improvement Project (Engineering Service (approx. \$21 million)

4. Debt Relief Measures for the Republic of Iraq

In November 2005, the Government of Japan signed the Exchange of Notes concerning the debt relief toward the Republic of Iraq, in which Japan agreed to cancel $80 \%$ in total of approximately 889,000 miffion yen (approximately 7,600 miffion dollars) in three stages; First stage: cancellation of 2.42 billion dollars after the signing of the Notes in November 2005, Second stage: cancellation of 2.40 
billion dollars. As for third stage, Japan will increase the rate of cancellation up to $80 \%$ of the total debts, upon completion of the IMF fs final review of the program.

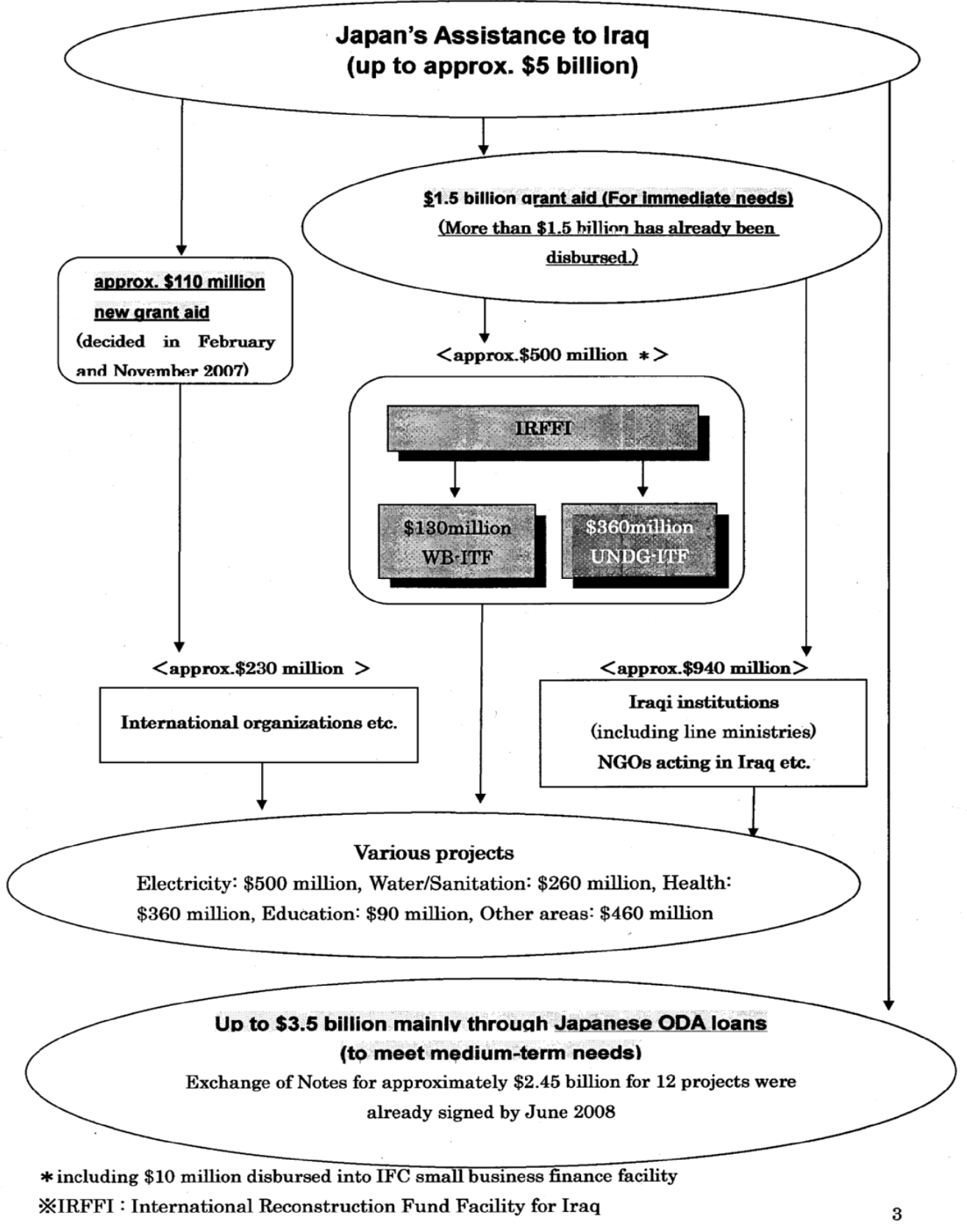

